\section{Wales woos global graduates}

\section{Valuable new scholarships are on offer to lure some of the world's most talented graduate students to Wales. Based at the University of Wales, the students will work with Welsh businesses on innovative products, ranging from nanotechnology devices to aerospace components. \\ Over the next three years, the 111.4 -million (US\$16.8-}

Innovation Scholarships programme will provide 100 students with an annual stipend of $€ 20,000$, a research grant of $£ 5,000$ and a tuition waiver. In return, the students are expected to generate new Wales-based products, patents or services.

When the gross domestic product per capita for Wales dipped below $75 \%$ of the European Union (EU) average in 1999, it qualified for funds from the European Regional Development Fund, an EU initiative to strengthen economic growth in struggling areas. From a second round of funding in 2006, University of Wales vice-chancellor Marc Clement combined $£ 5$ million in development funds with core university funds to promote a knowledge economy focused on innovation. By embedding the students in industry, Clement wants to provide an opportunity for young researchers to see first-hand how their ideas can have practical results. A statement by Welsh venture capitalist Michael Moritz caught his ear - that the founders of some of million) Prince of Wales the most successful companies are younger

\section{than 26, non-American, with} backgrounds in science, technology or medicine. "UK scholarships are often limited to UK or EU applicants. These scholarships allow anybody in the world to come to Wales to study," says Steve Conlan, co-director of Swansea University's Centre for NanoHealth. Conlan says that Swansea's School of Medicine is actively working to take advantage of the scholarship scheme. "We don't have coal mining any more, and little heavy industry, so we are looking for high-tech, high-value industries to sustain our economic future," he says.

Clement is forging partnerships with companies and universities around the world. He says the scholarships will focus on building synergies between academia and companies in priority sectors defined by the Welsh Assembly government, such as life sciences, engineering, information and communication technologies, and environmental technologies. He has met representatives of top research universities to discuss collaborations.

Steven Beckwith, vice-president for research and graduate studies at the University of California, says the university will advertise the programme to its students. "Time will tell if it will work," he says. "But it is an intriguing way to teach graduate students how the new knowledge they create in an academic setting can be applied to industry."

Virginia Gewin

\section{POSTDOC JOURNAL}

\section{Presentation dreams}

I can't sit still. The speaker explains something, shines a vibrant green dot on a screen scarred with graphs and data points, but my mind can't grasp her words. My left leg is bouncing. Stuttering applause spreads across the room. As in a dream, I walk behind the podium and face the crowd.

My first carefully rehearsed words tumble over the upturned faces. Others follow, efficient, eager. An excited choreographer on opening night, I watch the words dance for a moment, and then disappear off stage right. I am relaxed, enjoying myself. Even the sleeping man whose head leans backward, mouth open, does not dampen my elation.

I hear the applause and walk offstage, able now to follow the remaining talks. The crowd filters out, leaving clumps of questioners around the speakers. My co-author shakes my hand and says I did a good job. A moment later he is cornered by a grey-haired professor who slides in front of me. Left alone, I stand awkwardly, looking at groups congregated around the other speakers. I shoulder my backpack and leave the room. Conference presentations should be an opportunity to make a name for myself. Instead, each one is a parabola of nervousness, elation and disappointment. But maybe, if I keep working, next time I'Il nucleate my own crowd. I imagine that this will help reviewers and search committees recognize my be noticed, interviews will materialize, and I'll be that much closer to my dream of a professorship. Sam Walcott is a postdoc in theoretical biophysics at Johns Hopkins University in Baltimore, Maryland. name. Hence, my papers will

\section{IN BRIEF}

\section{Applications slowing}

International graduate applications to US institutes for 2009 increased at a lower rate than in previous years, according to a 7 April report from the US Council of Graduate Schools (CGS).

"We are seeing continuation of trend," says Nathan Bell, CGS director of research and policy analysis. The data, based on 400,000 applications collected this year, should reflect initial effects of the global recession, says Bell. Applications were up by $4 \%$, compared with $6 \%$ last year. Those from India and South Korea fell by $9 \%$ and $7 \%$, respectively, but those from China rose by $16 \%$. Global applications to physical sciences and engineering programmes slowed to a $4 \%$ gain after $7 \%$ last year.

Applications in life sciences fell by $2 \%$ after gaining $3 \%$ last year. This could be a one-time occurrence or part of a larger trend, Bell says.

\section{More PhDs for minorities}

The Alliances for Graduate Education and the Professoriate (AGEP), a programme funded by the US National Science Foundation (NSF), has helped increase the number of underrepresented minorities receiving $\mathrm{PhDs}$ in science, according to an analysis by the American Association for the Advancement of Science (AAAS).

Although the most recent NSF data show no discernible increase in the overall number of minority $\mathrm{PhDs}$, the AAAS analysis of 66 AGEP institutions found a $33.9 \%$ increase between 2001 and 2008 , with a $50 \%$ increase in natural sciences and engineering. Report co-author Yolanda George, deputy director of the AAAS education and human resources programmes, credits institutions for focusing on academic support and paying greater attention to recruiting and tracking minorities.

\section{Responsible research}

Conducting research responsibly is the focus of a new guide from the US National Academies. Aimed at early-career scientists and their mentors, On Being $a$ Scientist: A Guide to Responsible Conduct in Research addresses such questions as how to allocate credit for a discovery among a team, how to respond to errors in published works, and how to recognize conflicts of interest that could influence study results. Examples include some recent real-world cases of misconduct. 